\title{
Vitamin E (a tocopherol) attenuates toxicity and oxidative stress induced by aflatoxin in rats
}

\author{
Seval YIImaz ${ }^{1, A-F}$, Emre Kaya ${ }^{1}, B, C, E$, Selim Comakli2, B, C, E \\ ${ }^{1}$ Department of Biochemistry, Faculty of Veterinary Medicine, Firat University, Elazig, Turkey \\ ${ }^{2}$ Department of Pathology, Faculty of Veterinary Medicine, Ataturk University, Erzurum, Turkey \\ A - research concept and design; $\mathrm{B}$ - collection and/or assembly of data; $\mathrm{C}$ - data analysis and interpretation; \\ $D$ - writing the article; $E$ - critical revision of the article; $F$ - final approval of article
}

\section{Seval YIImaz \\ E-mail: sevyilars@yahoo.com \\ Funding sources \\ None declared \\ Conflict of interest \\ None declared}

Address for correspondence

Received on May 27, 2016

Revised on June 15,2016

Accepted on 0ctober 25, 2016

\section{Abstract}

Background. Aflatoxins are toxic metabolites produced by Aspergillus flavus and Aspergillus parasiticus and are classified as group I carcinogens by the International Agency for Research on Cancer (IARC).

Objectives. The purpose of this study was to investigate the possible preventive role of vitamin $\mathrm{E}(\mathrm{Vit} E)$ on aflatoxin (AF) induced toxicity by using biochemical and histopathological approaches.

Material and methods. Wistar-Albino rats were divided into 4 groups as follows: control group, Vit E group (Vit $E$ was administered), $A F B_{1}$ group (a single dose of $A F B_{1}$ was administered), $A F+V i t E$ group ( $A F$ and Vit $E$ were administered). The effects of Vit $E$ on $A F B_{1}$ induced tissue toxicity were evaluated by using malondialdehyde (MDA), reduced glutathione (GSH) levels, antioxidant enzyme activities, and histopathological examination in tissues.

Results. AF caused the oxidative stress by the increased MDA level and the reduced GSH level, glutathione-S-transferase (GST), catalase (CAT), glutathione peroxidase (GSH-Px), superoxide dismutase (SOD), and glucose-6-phosphate dehydrogenase (G6PD) activities in tissues. Plasma aspartate transaminase (AST), alanine transaminase (ALT), alkaline phosphatase (ALP), lactate dehydrogenase (LDH) activities, creatinine, and urea concentrations significantly increased; whereas, chloride, phosphorus, and magnesium concentrations were insignificantly affected. Plasma glucose, protein and sodium concentrations significantly decreased. Administration of AF caused hepatotoxicity, cardiotoxicity, and nephrotoxicity. As far as histopathological changes are concerned, a statistically significant difference was found in $A F B_{1}$ group compared to the control group. Vit E considerably reduced plasma AST, ALT, ALP, LDH activities, and urea concentration and ameliorated the deleterious effects of AF on oxidative stress markers and pathological changes.

Conclusions. This data indicated that the natural antioxidant Vit E might have a protective effect against AF-induced toxicity and oxidative stress.

Key words: oxidative stress, antioxidant, aflatoxin, vitamin E

DOI

10.17219/acem/66347

\section{Copyright}

Copyright by Author(s)

This is an article distributed under the terms of the

Creative Commons Attribution Non-Commercial License

(http://creativecommons.org/licenses/by-nc-nd/4.0/) 
Aflatoxins (AF) are polysubstituted bifuranocoumarins that are secondary fungal metabolites produced by parasiticus/ flavus group of the genus Aspergillus. AF-contaminated feeds may cause many health problems among livestock. AF is a carcinogen when administered in repeated doses in many animal species. $\mathrm{AFB}_{1}$ is nephrotoxic, hepatotoxic, mutagenic, genotoxic, and immunotoxic. ${ }^{1-5}$

$\mathrm{AFB}_{1}$ mediated cell injury may be due to the release of free radicals and these radicals initiate lipid peroxidation (LPO) and a damaging process in biological systems since all cell membranes contain the polyunsaturated fatty acids which are substrates for such a reaction. ${ }^{6}$ Kodama et al. showed the formation of LPO by $\mathrm{AFB}_{1}$. Oxidative stress is thought to play an important role in $\mathrm{AFB}_{1}$ by increasing LPO and decreasing antioxidants in treated animals. ${ }^{7-9}$

Vitamin E ( $\alpha$-tocopherol) is a lipophilic alcohol and its food source is the root of wheat and vegetable oils. The most important part of this substance is the $\alpha$-part because it constitutes $90 \%$ of the tocopherol composition of animal tissues. Many physiological functions including stabilization of membrane have been taken into consideration for this substance. This substance can absorb free radicals of oxygen and thus prevent the negative effects of LPO in the brain tissue. ${ }^{10-12}$

In the present study, the protective effect of Vit $\mathrm{E}$ was investigated by estimating malondialdehyde (MDA), reduced glutathione (GSH) levels and antioxidant enzymes such as glutathione-S-transferase (GST), catalase (CAT), glutathione peroxidase (GSH-Px), superoxide dismutase (SOD), and glucose-6-phosphate dehydrogenase (G6PD) activities in liver, kidney and heart of $\mathrm{AFB}_{1}$ treated rats.

\section{Material and methods}

\section{Chemicals}

$\mathrm{AFB}_{1}(5 \mathrm{mg}$, Code 11293) was purchased from Cayman Chemical Company (Michigan, USA), Vit E ( $\alpha$-tocopherol from vegetable oil, Code T3634), GSH, glutathione reductase, thiobarbituric acid, hydrogen peroxide, nicotinamide adenine dinucleotide phosphate (NADPH) and other reagents were supplied from Sigma (St. Louis, MO, USA).

\section{Preparation of $\mathrm{AFB}_{1}$ and Vit E}

$\mathrm{AFB}_{1}$ was dissolved in dimethyl sulfoxide (DMSO), diluted with distilled water, and then administered to the experimental animals. ${ }^{8}$ Vit E ( $\alpha$-tocopherol ampoule) was dissolved in corn oil and administered at the dose of $100 \mathrm{mg} / \mathrm{kg}$.

\section{Experimental groups and sample collection}

Twenty-eight healthy male Wistar-Albino rats (300$350 \mathrm{~g}$ body weight) were used in this study. The protocol for the use of animals was approved by the National Institutes of Health and Committee on Animal Research. $\mathrm{AFB}_{1}(1.0 \mathrm{~mL})$ was a single intraperitoneal (i.p.) dose administered to the animals at the dose of $2.5 \mathrm{mg} /$ $\mathrm{kg}$ b.w. Vit E (1.0 mL) was suspended in corn oil and administered to the animals by gavage at the dose of $100 \mathrm{mg} / \mathrm{kg} /$ day for 20 days. The doses of AF and Vit $\mathrm{E}$ used in this study were selected according to previous studies in which Vit $\mathrm{E}$ was administered together with AF. ${ }^{13-16}$ The animals were randomly divided into 4 experimental groups including 7 rats in each. These groups were arranged as follows: control group, Vit E group (Vit $\mathrm{E}$ was administered), $\mathrm{AFB}_{1}$ group (a single dose of $\mathrm{AFB}_{1}$ was administered), $\mathrm{AF}+\mathrm{Vit} \mathrm{E}$ group (AF and Vit $\mathrm{E}$ were administered).

\section{Biochemical analysis}

Under ether anesthesia, blood samples were withdrawn by an injector from the heart of the animals and collected into tubes containing EDTA. At the end of the experiment, the rats in control and experimental groups were sacrificed by decapitation under ether anesthesia.

Plasma was used to measure MDA level as a marker of LPO and to determine aspartate transaminase (AST), alanine transaminase (ALT), alkaine phosphatase (ALP), lactate dehydrogenase (LDH) activities, glucose, protein, creatinine, urea, sodium, chloride, phosphorus, and magnesium concentrations. Tissue samples were quickly removed and perfused with ice-cold saline for biochemical and histopathological evaluation. The tissues were homogenized in distilled water by using a Potter-elvehjem Homogenizer. The homogenate was centrifuged (at 3.500 rpm for $15 \mathrm{~min}$ to MDA, GSH, GST, CAT, SOD analyze and at $14.000 \mathrm{rpm}$ for $55 \mathrm{~min}$ to GSH-Px and G6PD at $\left.+4^{\circ} \mathrm{C}\right)$.

MDA and GSH levels, GST, CAT, GSH-Px, SOD and G6PD activities were analyzed in liver, kidney and heart tissues. While MDA level was measured according to the method developed by Placer et al., the GSH level was determined by the method developed by Ellman et al. ${ }^{17,18}$ GST activity was measured by the method developed by Habig et al. ${ }^{19}$ CAT activity was carried out by using Aebi's method. ${ }^{20}$ GSH-Px activity was measured by the Beutler method. ${ }^{21}$ SOD activity was measured by using xanthine and xanthine oxidases to generate superoxide radicals reacting with nitroblue tetrazolium. ${ }^{22}$ G6PD activity was measured by the Beutler method. ${ }^{21}$ The protein concentration determination was based on the method of Lowry et al. ${ }^{23}$ The plasma glucose, protein, creatinine, urea, sodium, chloride, phosphorus and magnesium were 
measured by using an AutoAnalyzer (Olympus AU 600, Tokyo, Japan).

\section{Histopathological examination}

Necropsy of the rats was performed and liver, kidney, and heart tissue samples were fixed at $10 \%$ neutral buffered formalin. Paraffin embedded blocks were routinely processed. 5- $\mu \mathrm{m}$ thick sections were stained with hematoxylin-eosin and examined under a microscope. Then random 10 microscopic fields were examined in $\times 40$ magnification.

\section{Statistical analysis}

The results are expressed as mean \pm standard error. Statistical significance between the different groups was determined by using a one-way analysis of variance (ANOVA) in the SPSS 21 software package. Post hoc test was performed for between-group comparisons by using the Tukey multiple comparison test. The level of significance was set at $\mathrm{p}<0.001$.

\section{Results}

\section{MDA and GSH levels}

Figures 1-3 show the tissue MDA levels, GSH levels and the activities of antioxidant enzymes such as GST, CAT, GSH-Px, SOD, and G6PD in the control and experimental groups. The data indicated that the $\mathrm{AFB}_{1}$ group had a significantly higher MDA level than the control group in all the tissues. The Vit $\mathrm{E}$ group had a significantly lower MDA level than the $\mathrm{AFB}_{1}$ group. Treatment with $\mathrm{AFB}_{1}$ and Vit $\mathrm{E}$ provided apparent normalization in MDA level compared to the AF group. GSH level significantly decreased in the $\mathrm{AFB}_{1}$ group compared to the control group. Upon supplementation of Vit $\mathrm{E}$ to the $\mathrm{AFB}_{1}$ group, a significant increase was observed in the GSH level compared to that of the $\mathrm{AFB}_{1}$ group. The GSH level was restored in the $\mathrm{AFB}_{1}$ and the Vit $\mathrm{E}$ group.

\section{GST, CAT, GSH-Px, SOD and G6PD enzyme activities}

A significant reduction was found in GST, CAT, GSH-Px, SOD and G6PD activities in the $\mathrm{AFB}_{1}$ group compared to that of the control group. Upon simultaneous supplementation of Vit $\mathrm{E}$ to the $\mathrm{AFB}_{1}$ group, significant increases were observed in antioxidant enzyme activities compared to the $\mathrm{AFB}_{1}$ group. With the addition of Vit $\mathrm{E}$ to $\mathrm{AF}$, normal values were reached $(\mathrm{p}<0.001, \mathrm{p}<0.05)$.

\section{Biochemical parameters}

Fig. 4 shows the biochemical parameters such as AST, ALT, ALP, LDH, glucose, protein, creatinine, urea, sodium, chloride, phosphorus and magnesium in the control and experimental groups. Plasma AST, ALT, ALP, $\mathrm{LDH}$, creatinine, and urea concentrations were significantly higher after administration of $\mathrm{AFB}_{1}$ compared to the control group. Administration of $\mathrm{AFB}_{1}$ alone induced a significant decrease in plasma glucose, protein, sodium concentration, however; it did not induce a significant effect on plasma chloride, phosphorus, and magnesium concentrations. Plasma AST, ALT, ALP, LDH activities, glucose, protein and urea concentrations in $\mathrm{AFB}_{1}+\mathrm{Vit} \mathrm{E}$ group were lower than those determined in $\mathrm{AFB}_{1}$ group. Plasma creatinine concentration in $\mathrm{AFB}_{1}+\mathrm{Vit} \mathrm{E}$ group was lower than $A F B_{1}$ group, but this value could not reach the control level. Administration of $\mathrm{AFB}_{1}$ alone did not cause a significant change in plasma chloride, phosphorus, and magnesium concentrations ( $\mathrm{p}<0.001, \mathrm{p}<0.05)$.

\section{Histopathological examination}

The histological changes in the tissues were assessed as defined in Fig. 5-7. Control and Vit E groups had a normal histological appearance in liver, kidney, and heart tissues. As histopathological changes, a statistically significant difference was found in the $\mathrm{AFB}_{1}$ group compared to the control group $(\mathrm{p}<0.05)$.

While severe necrotic hepatocytes and hydropic degeneration were observed in liver tissues of the $A F B_{1}$ group, it was determined that these changes reduced in $\mathrm{AFB}_{1}$ with Vit E group (Fig. 5). Administration of $\mathrm{AFB}_{1}$ caused severe tubular necrosis, tubular degeneration, and hyaline droplets in kidney tissues. However, administration of Vit $\mathrm{E}$ ameliorated severe tubular necrosis and degeneration, and hyaline droplets (Fig. 6). Administration of $\mathrm{AFB}_{1}$ caused a severe hemorrhage and degenerative changes in heart tissues. Rats treated with $\mathrm{AFB}_{1}+\mathrm{Vit} \mathrm{E}$ had lower hemorrhage and degenerative changes (Fig. 7).

\section{Discussion}

One of causes for $\mathrm{AFB}_{1}$ induced toxicity is the oxidative stress which caused improved reactive oxygen species (ROS) generation and oxidative DNA damage. ${ }^{24,25}$ Previous studies, using different animal species, indicated that AF induced changes in oxidative stress markers. ${ }^{6,26-29}$ This study was conducted to assess the effect of AF on oxidative stress signs in rat liver, heart and kidney tissues.

According to $\mathrm{AFB}_{1}$ concentration, the organs were classed as follows: gonads, liver, kidney, spleen, bursa cloacalis, thymus, endocrine glands, muscles, lungs, and the brain. ${ }^{30}$ Petr et al. ${ }^{31}$ revealed that $\mathrm{AFB}_{1}$ was determined in 
Fig. 1. Effect of Vit E on oxidant-antioxidant status in liver tissue of $A F B_{1}$ treated rats. MDA (nmol/g tissue), GSH ( $\mu \mathrm{mol} / \mathrm{mL}$ ), GST (U/mg protein), CAT (k/mg protein) GSH-Px (U/g protein), SOD (U/mg protein), G6PD (U/g protein)
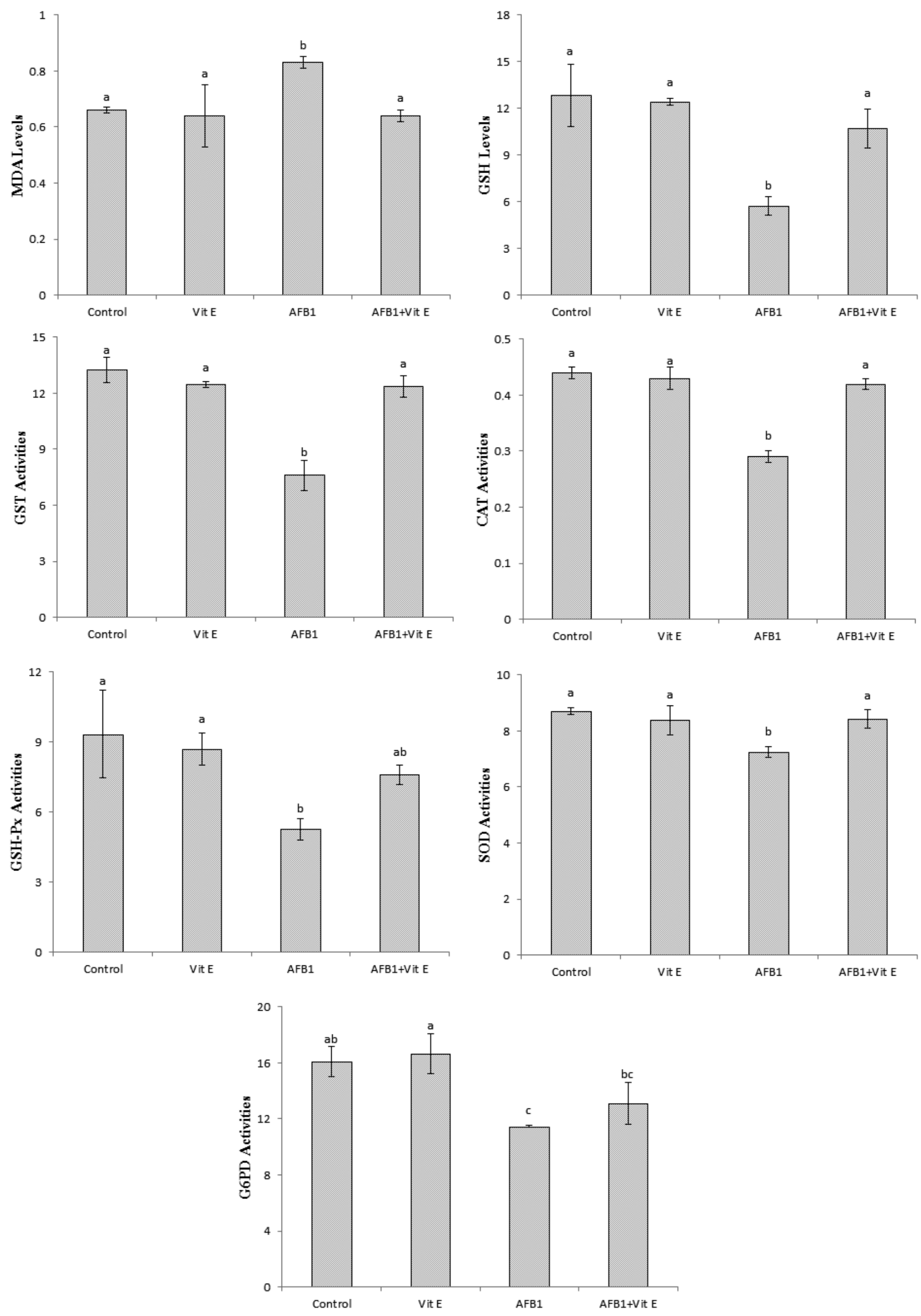
Fig. 2. Effect of Vit E on oxidant-antioxidant status in kidney tissue of AFB 1 treated rats. MDA (nmol/g tissue), GSH ( $\mu \mathrm{mol} / \mathrm{mL}), \mathrm{GST}(\mathrm{U} / \mathrm{mg} \mathrm{protein})$, CAT (k/g protein) GSH-Px (U/g protein), SOD (U/mg protein), G6PD (U/g protein)
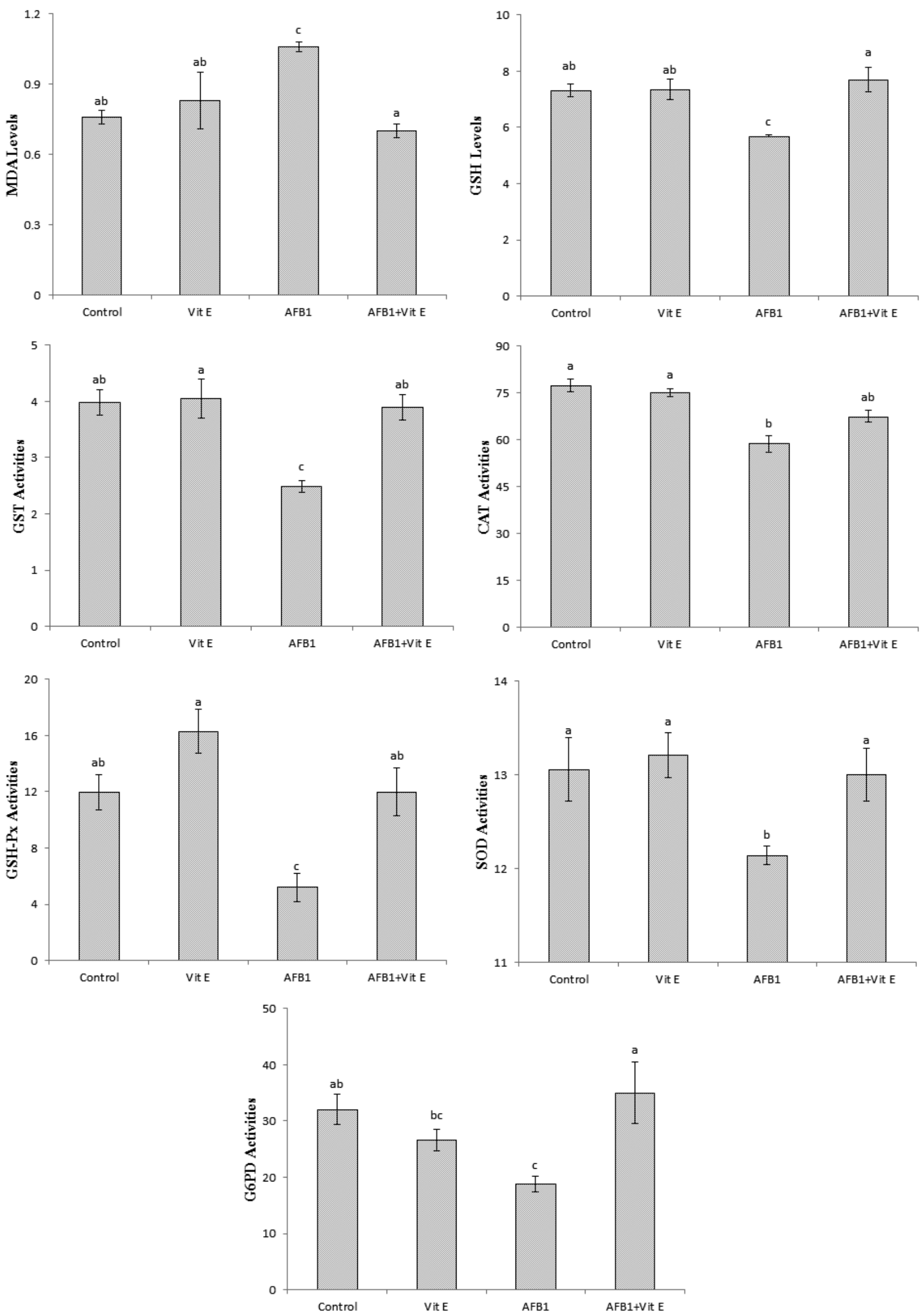
Fig. 3. Effect of Vit E on oxidant-antioxidant status in heart tissue of AFB treated rats. MDA (nmol/g tissue), GSH ( $\mu \mathrm{mol} / \mathrm{ml})$, GST (U/mg protein), CAT (k/g protein) GSH-Px (U/mg protein), SOD (U/mg protein), G6PD (U/g protein)
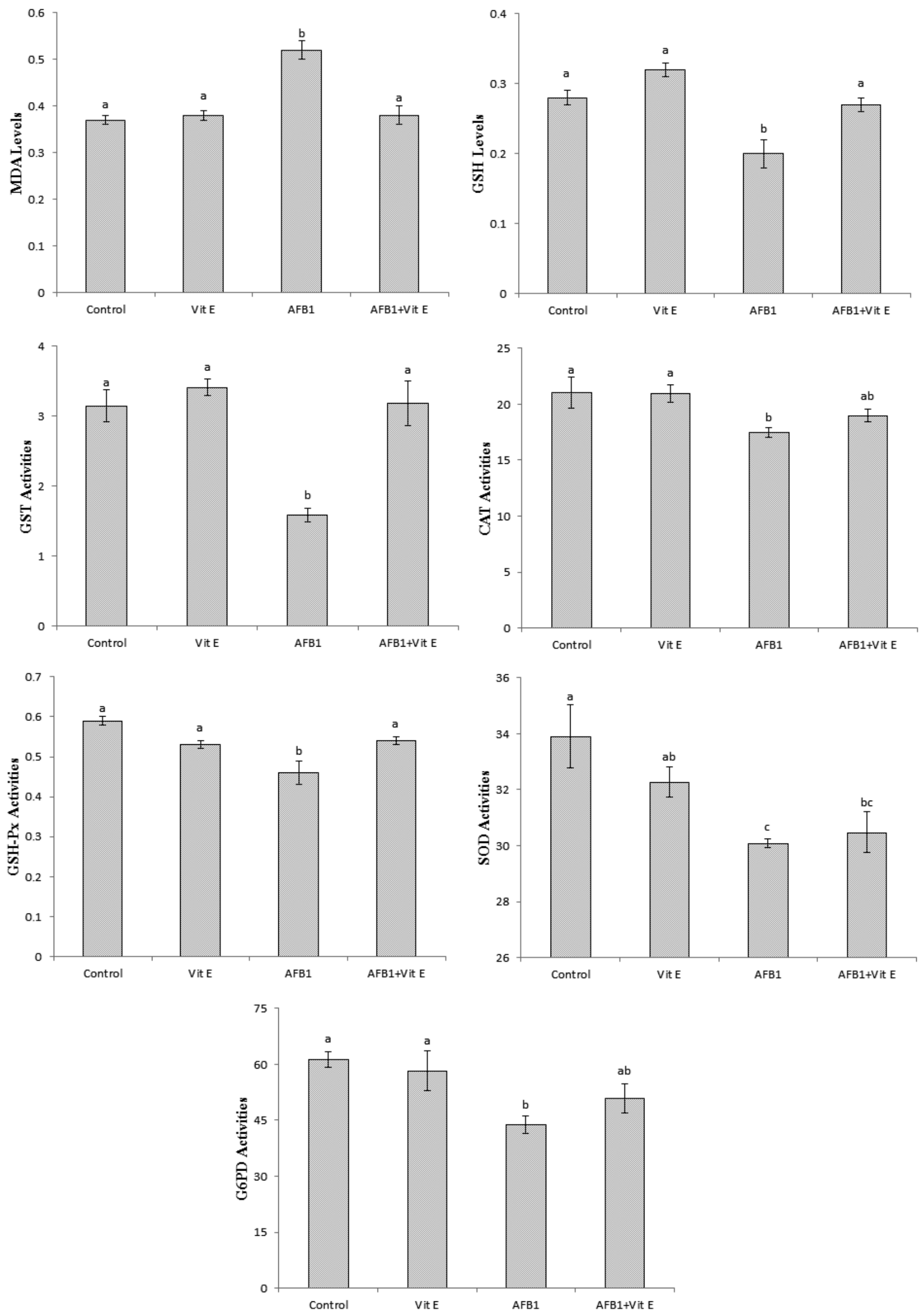
Fig. 4. Effect of Vit E on plasma $A S T(U / L), A L T(U / L), A L P(U / L), L D H(U / L)$, glucose (mg/dL), protein (g/dL), creatinine (mg/dL), urea $(\mathrm{mg} / \mathrm{dL})$, sodium ( $\mathrm{mmol} / \mathrm{L})$, chloride $(\mathrm{mmol} / \mathrm{L})$, phosphorus $(\mathrm{mg} / \mathrm{dL})$, magnesium $(\mathrm{mg} / \mathrm{dL})$ in $A F B_{1}$ treated rats
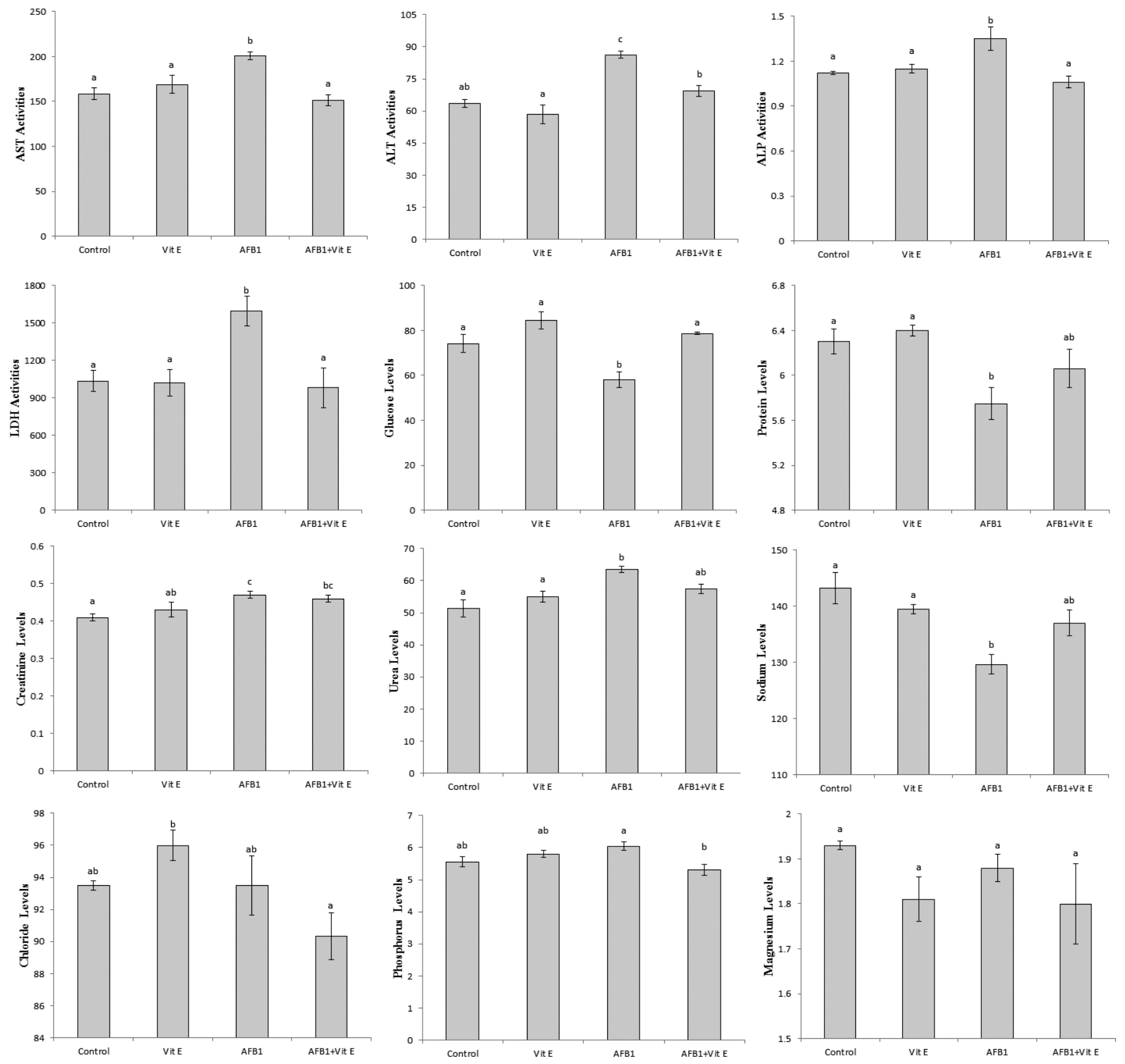

the blood, kidney, liver, and testis from minutes to maximum $8-10 \mathrm{~h}$ after a single i.p. injection at $0.1 \mathrm{mg} / \mathrm{kg} \mathrm{AFB}_{1}$.

The results showed that the administration of $\mathrm{AFB}_{1}$ produced a marked oxidative impact as evidenced by a significant increase in MDA in the liver, kidneys and heart of AF-treated rats. These alterations might have been triggered either by the direct effects of $\mathrm{AFB}_{1}$ or by the metabolites formed by AF and the free radicals, which were generated during the formation of these metabolites. This result is compatible with the results reported previously about rat tissues. ${ }^{32,33}$ Initiation of LPO by $\mathrm{AFB}_{1}$ is noted as one of the principal appearances of ROS-induced oxidative damage. The mechanism of free radical damage also includes $\mathrm{ROS}$-induced peroxidation of polyunsaturated fatty acids in the cell membrane lipid bilayer which causes a chain reaction of LPO, thus damaging the cellular membrane, causing further oxidation of membrane lipids and proteins, and leading to DNA damage. ${ }^{34}$ It is revealed that $\mathrm{AFB}_{1}$, with the help of microsomal cytochrome p-450 mediated oxidation, is biotransformed into $\mathrm{AFB}_{1}-8$-9-epoxide, which is a reactive intermediate and highly toxic. ${ }^{35}$

The present study also showed that a significant increase in the oxidative stress was accompanied by a concomitant decrease in the enzyme activities involved in the disposal of superoxide anions and peroxides, namely CAT and SOD, as well as GSH levels and its related enzymes (GST, GSH-Px). A significant increase observed 
Fig. 5. Sections of the liver in AFB, Vit E treated rats. livers of control a), Vit E treated rats b) show normal histological appearance. However, liver of AFB treated rats $\mathrm{C}$ ) shows severe necrotic changes in hepatocytes $\left(^{*}\right)$ and hydropic degeneration (arrowhead) in the hepatocytes. The liver of $A F B_{1}$ plus Vit $E$ treated rats $\mathrm{d}$ ) shows moderate necrotic changes in the hepatocytes $\left({ }^{*}\right.$ ) (haematoxylin and eosin staining, magnification $\times 40$ )
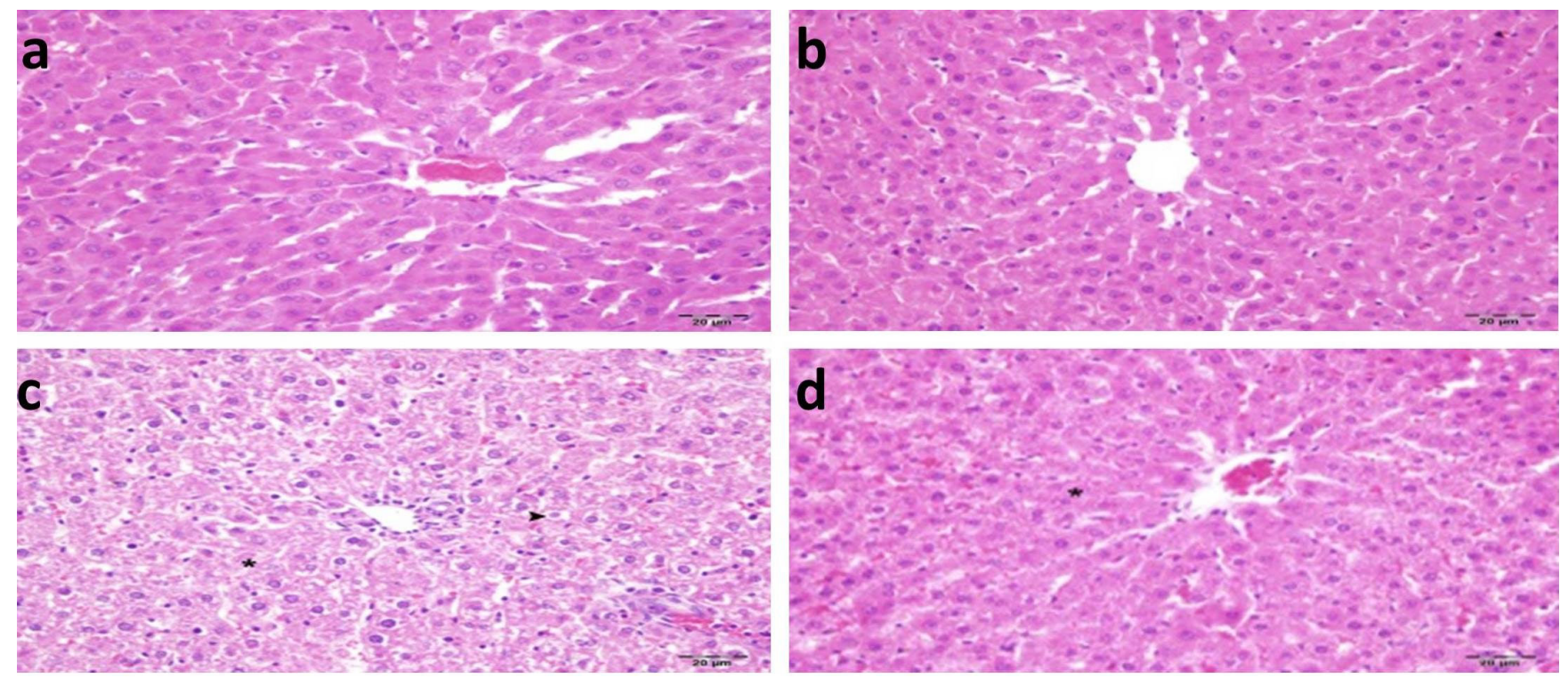

Fig. 6. Sections of the kidney in $\mathrm{AFB}_{1}$ and Vit E treated rats. kidneys of control a), Vit E treated rats b) show normal histological appearance. However, kidney of $\mathrm{AFB}_{1}$ treated rats $\mathrm{c}$ ) reveals severe degenerative changes, necrotic tubular epithelial cells $\left(^{*}\right)$ and hyaline droplets in the tubules (arrowheads). The kidney of $\mathrm{AFB}_{1}$ plus Vit E treated rats d) shows moderate degenerative changes, hyaline droplets in the tubules (arrowheads) (haematoxylin and eosin staining, magnification $\times 40)$
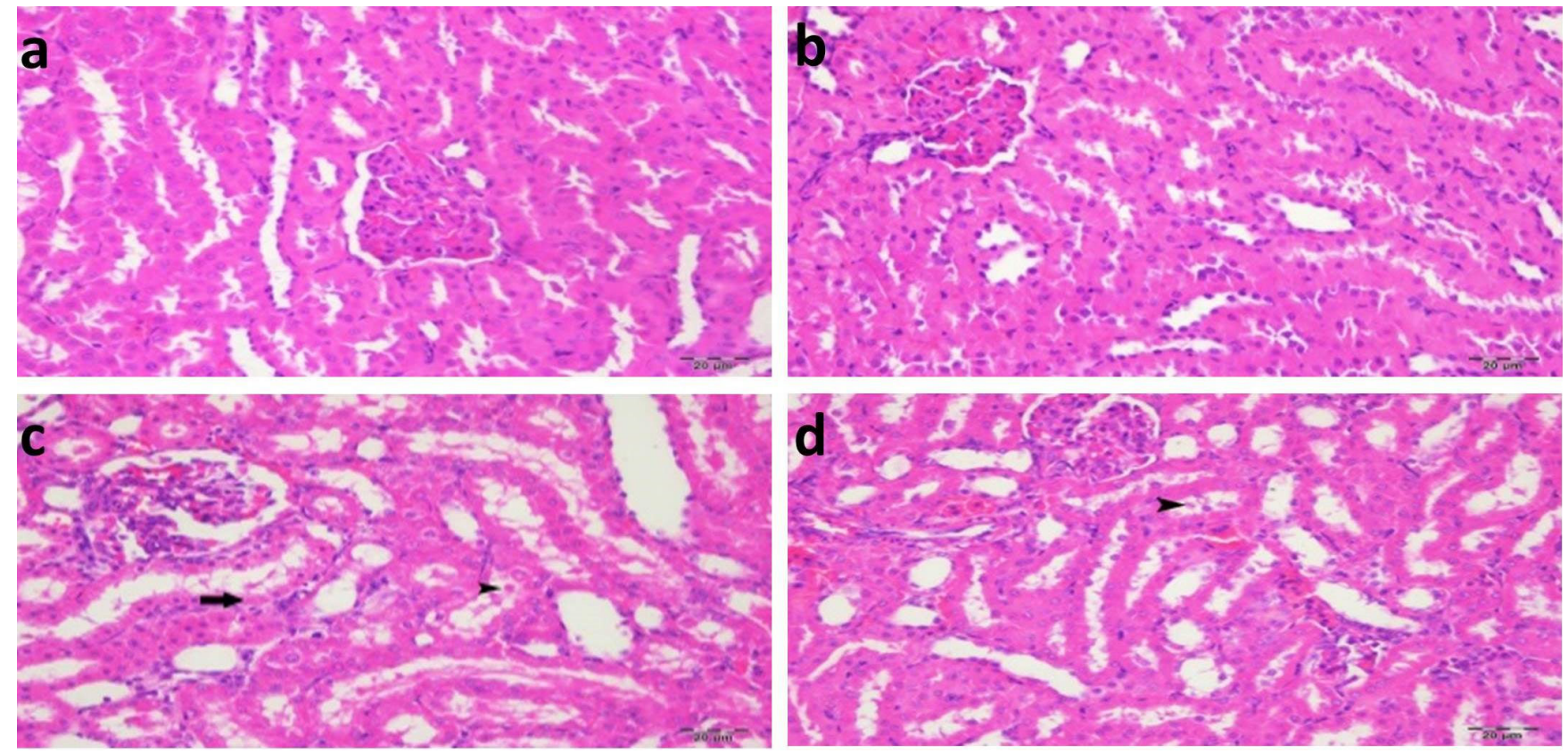

in tissue MDA levels in $\mathrm{AFB}_{1}$ treated animals indicated that AF led to the generation of high level of free radicals, which could not be tolerated by the cellular antioxidant defense system. A significant decrease in these enzyme activities could be explained by their consumption during the conversion of free radicals into less harmful or harmless metabolites. The enzyme activities decreased by $\mathrm{AFB}_{1}$ can be attributed to the lower ability of the tissue, which cannot scavenge free radicals and prevent the

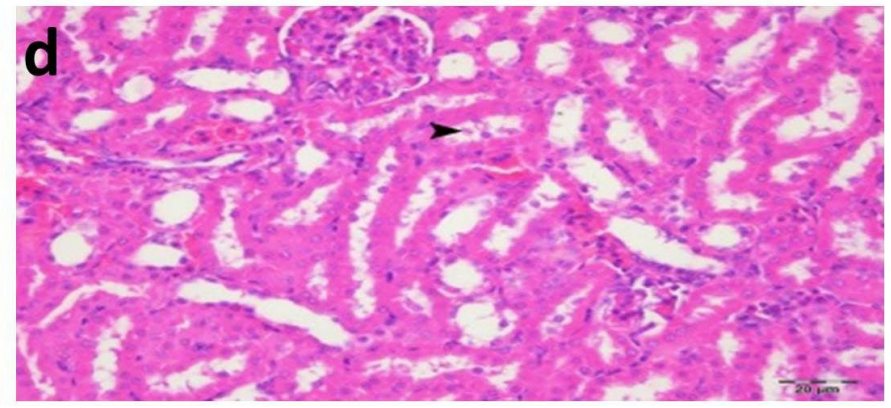

action of LPO. Similar results were also reported in previous studies. , $^{86-38}$

GSH and GST are effective in providing protection from the harmful effects on the tissues of $\mathrm{AFB}_{1} \cdot{ }^{39} \mathrm{GST}$ catalyzes the conjugation of $\mathrm{AFB}_{1}-8$, 9-epoxide with $\mathrm{GSH}$ to form $\mathrm{AFB}_{1}$-epoxide-GSH conjugate, thereby decreasing the intracellular GSH content. ${ }^{40,41}$ The activity of GSH-Px, which is a constituent of GSH redox cycle decreased during $\mathrm{AFB}_{1}$ administration. The reduction in the GSH-Px activity by $\mathrm{AFB}_{1}$ may be due to a decrease in 
Fig. 7. Sections of the heart in rats treated with AFB, Vit E. hearts of control a), Vit E treated rats b) show normal histological appearance. However, the heart of $A F B_{1}$ treated rats $C$ ) reveals degeneration, necrosis $(*)$, severe hemorrhages in the myocardium (arrowhead). The heart of $A F B_{1}$ plus $V$ it $E$ treated rats $d$ ) shows moderate hemorrhages in the myocardial tissue (arrowhead) (haematoxylin and eosin staining, magnification $\times 40$ )
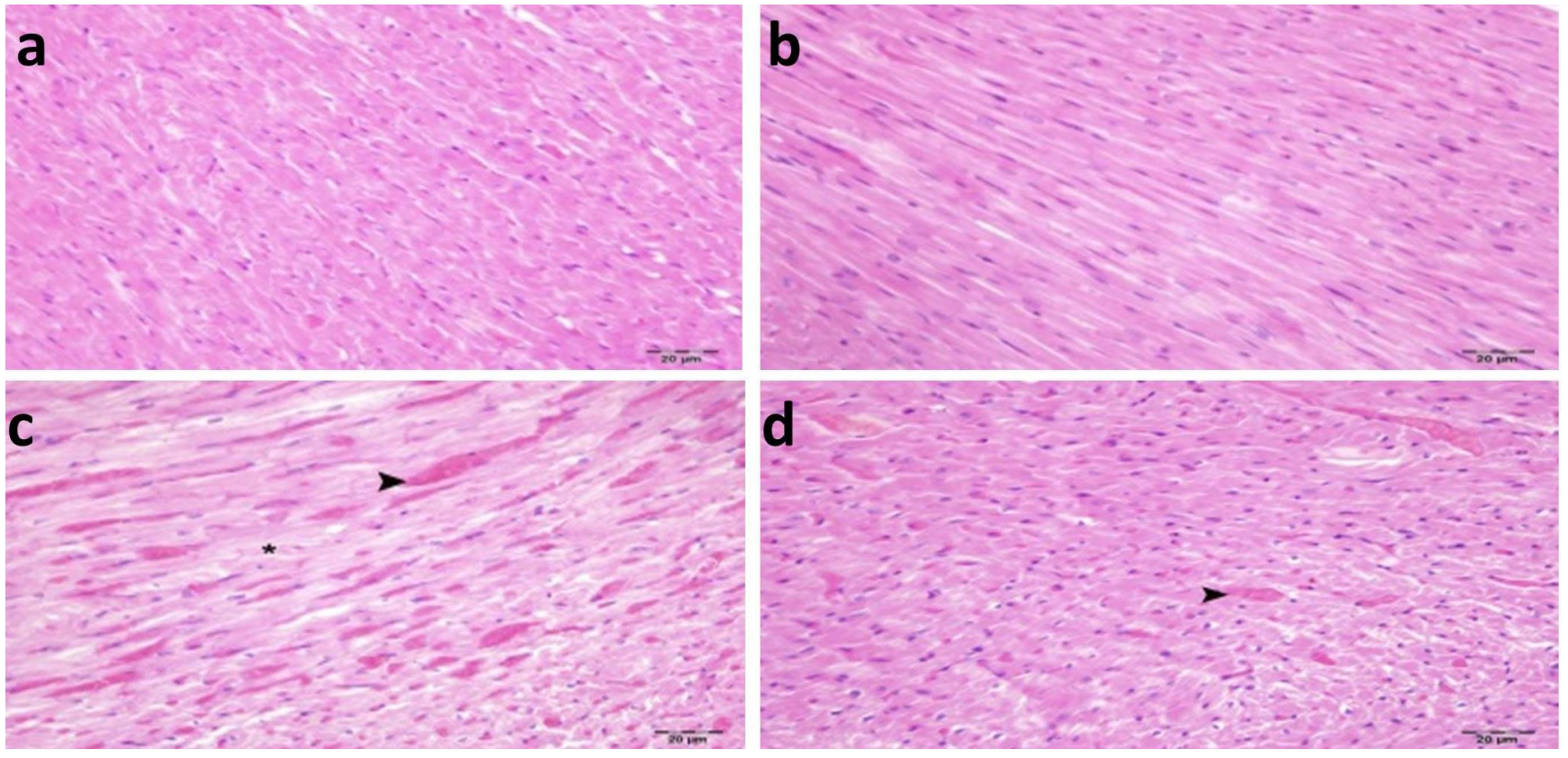

the availability of GSH and also alterations in their protein structure by ROS. ${ }^{32,39,42,43}$

The decreased G6PD activity as GSH metabolizing enzymes in $\mathrm{AFB}_{1}$-treated animals occurs as a result of decreased supply of reduced NADPH for the conversion of oxidized glutathione to GSH. Under conditions of oxidative attack, the $\mathrm{NADP}^{+} / \mathrm{NADPH}$ ratio changes in favor of $\mathrm{NADP}^{+}$, indicating decreased G6PD activity. ${ }^{44}$ The present study also showed a similar result in this enzyme activity and administration of Vit $\mathrm{E}$ significantly improved the G6PD activities.

Supplementation of Vit $\mathrm{E}$ to $\mathrm{AFB}_{1}$ significantly reduced MDA level and eliminated the possibility of oxidative stress due to the administration of $\mathrm{AFB}_{1}$ to rats. The antioxidative function of $\mathrm{Vit} \mathrm{E}$ is mainly due to its reaction to membrane phospholipid bilayers to break the chain reaction initiated by hydroxyl radicals. ${ }^{11,45}$ Vit $\mathrm{E}$ may inhibit free radical generation by direct scavenging of the free radicals and subsequent transformation of the antioxidant species into less toxic product. ${ }^{46,47}$ Vitamin $\mathrm{E}$ as a therapy for AF-treated rats can be effective to significantly increase GSH, CAT, GSH-Px and GST activities. Vit $\mathrm{E}$ increases the GSH levels, resulting in an increase in SOD activity, and thereby preventing the deleterious effect of superoxide radicals. The restoration of antioxidant enzyme activities and the GSH level of Vit E indicates that they play an important role in mitigating $\mathrm{AFB}_{1}$ induced oxidative stress and subsequent damage to the tissue. ${ }^{48}$ The results of the present study revealed that AF was potent hepatotoxic, nephrotoxic, and cardiotoxic and Vit E showed protection against AF-induced nephrotoxicity, hepatotoxicity, and cardiotoxicity.
The liver is considered the principal target organ for AF. ${ }^{1}$ The result of the study clearly indicated that the administration of AF caused a significantly higher level of plasma AST, ALT and ALP in rats. Increased activities of these enzymes are well known to be diagnostic indicators of hepatic injury. ALP is a membrane bound enzyme and its alteration is likely to affect the membrane permeability and produce a derangement in the transport of metabolite. The results of the present study indicated a significant improvement in these marker enzyme activities in plasma, which is compatible with the previous studies. ${ }^{49-52}$ In the present study, LDH levels increased significantly in $\mathrm{AFB}_{1}$-treated rats which indicated the presence of myocardial infraction, cardiac injury, and toxicity to cardiac tissue and was compatible with the previous studies suggesting that exposure to $\mathrm{AFB}_{1}$ causes heart defects. ${ }^{53-55}$ Increased levels of these enzymes might also be due to the leakage of enzymes from the kidney as a result of necrosis induced by $\mathrm{AFB}_{1}$. Administration of Vit E significantly reduced these enzyme levels. The morphological changes included severe necrotic hepatocytes and hydropic degeneration. The histopathological and biochemical actions may be due to its antioxidant effects. Histopathologically, the livers of $\mathrm{AFB}_{1}$ treated rats were observed to be extensive hepatocellular necrosis, fatty infiltration, and bile duct proliferation. ${ }^{56}$ Vayalil ${ }^{57}$ showed that the date fruit extract (Phoenix dactylifera $\mathrm{L}$. Arecaceae) induced liver protection against aflatoxicosis occurred via decreased liver enzyme activity as well as decreased free radical propagation, and also by its lowering the pathological lesions resulting from $\mathrm{AFB}_{1}$.

Histopathologically, the liver and kidney treated with 
$\mathrm{AFB}_{1}$ and Vit $\mathrm{E}$ showed less morphological changes compared to the changes seen in $\mathrm{AFB}_{1}$ alone, which was an indication of partial protection. The results support the presence of hepatoprotective and nephroprotective roles of Vit $\mathrm{E}$ and this might be due to the membrane stabilizing and antioxidant activity of Vit $\mathrm{E}$.

A significant decrease was found in plasma glucose and protein levels in AF-treated rats. This result is supported by the results of Abdulmajeed.$^{53}$ who indicated that aflatoxicosis affects the cellular energy supply of rat hearts by causing its inhibitory effects on some markers of the energy metabolism due to a decrease in glucose and glycogen contents of the heart tissue and a reduction in the activities of some glycolytic enzymes such as phosphogluco isomers and glyceraldehyde-3-phosphate dehydrogenase.

Decreased biosynthesis and secretion of proteins might be due to formation of AF adducts with DNA, RNA and protein. AFs were previously shown to lower the total protein concentration in serum of rabbits and broilers. ${ }^{58,59}$

Several studies have reported that the intoxication of $\mathrm{AFB}_{1}$ causes nephrotoxicity. ${ }^{60}$ Administration of $\mathrm{AF}$ caused a significantly higher concentration of plasma creatinine and urea. This result is compatible with results of Rati et al ${ }^{61}$ The heightened appearance of plasma creatinine of $\mathrm{AFB}_{1}$-treated rats indicates the increased transformation of phosphocreaine to creatinine in the muscle, which might be due to utilization of phosphocreatine in muscular contraction. Thus, the significant increase in creatinine concentration in plasma could be due to the increased release of muscles and/or decrease excretion from the kidney. The increased levels of plasma urea and creatinine with decreased levels of plasma protein may indicate protein catabolism and kidney dysfunction. ${ }^{62}$ Verma and Raval ${ }^{63}$ reported the occurrence of nephrotoxicity and the elevation of creatinine in serum and urine of rabbits receiving $15 \mathrm{mg} / \mathrm{kg}$ AF-contaminated feed for 60 days. Histopathological studies revealed tubular necrotic degeneration in the kidney of $\mathrm{AFB}_{1}$-treated rat. A histological examination of kidneys demonstrated previously mentioned microscopic changes that were compatible with the kidney dysfunction showed by biochemical tests. It could be concluded that nephrotoxicity induced by $\mathrm{AFB}_{1}$ affects the tubulointerstitial structure histologically. Vit $\mathrm{E}$ ameliorates changes in experimental glomerulopathy, which is associated with increased renal oxidant injury. Preservation of the tubular architecture was evident in $\mathrm{AFB}_{1}+\mathrm{Vit} \mathrm{E}$ group in the present study.

In conclusion, results of the present suggest that AF has a harmful and stressful effect on hepatic, renal and cardiac tissue. Treatment of Vit $\mathrm{E}$ may alleviate AF toxicity by the reduction of oxidative damage of AF in liver, renal, and cardiac tissues and alterations of cardiac energy metabolism. For this reason, Vit E can be regarded as a good therapeutic agent against aflatoxicosis.

\section{References}

1. Abdel-Wahhab MA, Aly SE. Antioxidant property of Nigella sativa (black cumin) and Syzygium aromaticum (clove) in rats during aflatoxicosis. J Appl Toxicol. 2005;25:218-123.

2. Corcuera LA, Ibanez-Vea M, Vettorazzi A, Gonzalez-Penas E, Cerain AL. Validation of a UHPLC-FLD analytical method for the simultaneous quantification of aflatoxin B1 and ochratoxin a in rat plasma, liver and kidney. J Chromatogr B: Analyt Technol Biomed Life Sci. 2011;879:2733-2740.

3. Marin S, Ramos AJ, Cano-Sancho G, Sanchis V. Mycotoxins: Occurrence, toxicology, and exposure assessment. Food Chem Toxicol. 2013;60:218-237.

4. Ahmad M, Ahmad MM, Hamid R, Abdin MZ, Javed S. Use of response surfacemethodology to study the effect of media composition on aflatoxin productionby Aspergillus flavus. Mycotoxin Res. 2013;29:39-45.

5. Stoev SD. Foodborne mycotoxicoses risk assessment and underestimated hazard of masked mycotoxins and joint mycotoxin effects or interaction. Environ Toxicol Pharmacol. 2015;39:794-809.

6. Shen HM, Shi CY, Lee HP, Ong CN. Aflatoxin B 1-induced lipid peroxidation in rat liver. Toxicol Appl Pharmacol. 1994;127:145-150.

7. Kodama M, Inoue F, Akao M. Enzymatic and non-enzymatic formation of free radicals from aflatoxin B1. Free radical research communications. 1990;10:137-142.

8. Gupta R, Sharma V. Ameliorative effects of tinospora cordifolia root extract on histopathological and biochemical changes induced by aflatoxin-B(1) in mice kidney. Toxicol Int. 2011;18:94-98.

9. Liao $S$, Shi $D$, Clemons-Chevis $C L$, et al. Protective role of selenium on aflatoxin B1-induced hepatic dysfunction and apoptosis of liver inducklings. Biol Trace Elem Res. 2014;162:296-301.

10. Brigelius-Flohe R, Traber MG. Vitamin E: Function and metabolism. The FASEB J. 1999;13:1145-1155.

11. Traber MG, Atkinson J. Vitamin E antioxidant and nothing more. Free Radic Biol Med. 2007;43:4-15.

12. Lebold KM, Traber MG. Interactions between alpha-tocopherol, poly unsaturated fatty acids, and lipoxygenases during embryogenesis. Free Radic Biol Med. 2014;66:13-19.

13. Dycaico MJ, Stuart GR, Tobal GM, De Boer JG, Glickman BW, Provost GS. Species-specific differences in hepatic mutant frequency and mutational spectrum among lambda/lacl transgenic rats and mice following exposure to aflatoxin B1. Carcinogenesis. 1996;17:2347-2356.

14. Hiruma S, Qin GZ, Gopalan-Kriczky P, Shinozuka H, Sato K, Lotlikar PD. Effect of cell proliferation on initiation of aflatoxin B1-induced enzyme altered hepatic foci in rats and hamsters. Carcinogenesis. 1996;17:2495-2499.

15. El-Demerdash FM, Yousef MI, Kedwany FS, Baghdadi HH. Cadmiuminduced changes in lipid peroxidation, blood hematology, biochemical parameters and semen quality of male rats: Protective role of vitamin E and $\beta$-carotene. Food Chem Toxicol. 2004;42:1563-1571.

16. Yousef MI, Awad TI, Mohamed EH. Deltamethrin-induced oxidative damage and biochemical alterations in rat and its attenuation by vitamin E. Toxicology. 2006;227:240-247.

17. Placer ZA, Cushman L, Johnson BC. Estimation of products of lipid peroxidation in biological fluids. Anal Biochem. 1966;16:359-364.

18. Ellman GL, Courtney KD, Andres V, Featherstone RM. A new and rapid colorimetric determination of acetylcholinesterase activity. Biochem Pharmacol. 1961;7:88-95.

19. Habig WH, Pabst MJ, Jakoby WB. Glutathione S-transferases the first enzymatic step in mercapturic acid formation. J Biol Chem. 1974;249:7130-7139.

20. Aebi H. Catalase in vitro. Methods Enzymol. 1984;105:121-126.

21. Beutler E. Active transport of glutathione disulfide from erythrocytes. Functions of Glutathione-Biochemical. Physiological, Toxicological and Clinical Aspects, edited by Larson A, Orrenius S, Holmgren A, Mannerwik B, Raven Press, New York, USA, 65, 1983.

22. Sun Y, Oberly LW, Ying LA. Simple method for clinical assay of superoxide dismutase. Clin Chem. 1988;34:497-500.

23. Lowry $\mathrm{OH}$, Rosebrough NJ, Farr AL, Randall RJ. Protein measurement with the folin phenol reagent. J Boil Chem. 1951;193:265-275.

24. Souza MF, Tome AR, Rao VS. Inhibition by the bioflavonoid terna- 
tin of AFB1 induced lipid peroxidation in rat liver. J Pharm Pharmacol. 1999;51:125-129.

25. Verma RJ, Mathuria N. Effect of curcumin on aflatoxin-induced biochemical changes in testis of mice. Fertil Steril. 2009;91:597-601.

26. Eraslan G, Akdoğan M, Yarsan E, Sahindokuyucu F, Essiz D, Altintas L. The effects of aflatoxins on oxidative stress in broiler chickens. Turk J Vet Anim Sci. 2005;29:701-707.

27. Eraslan G, Cam Y, Eren M, Liman BC, Atalay O, Seybek N. Aspects of using $\mathrm{N}$-Acetylcysteine in aflatoxicosis and its evaluation regarding some lipid peroxidation parameters in rabbits. Bull Vet Inst Pulawy. 2005;49:243-247.

28. Mathuria N, Verma RJ. Curcumin ameliorates aflatoxininduced lipid peroxidation in liver, kidney and testis of mice-an in vitro study. Acta Pol Pharm. 2007;64:413-416.

29. Verma RJ, Mathuria N. Curcumin ameliorates aflatoxin induced lipid peroxidation in liver and kidney of mice. Acta Pol Pharm. 2008;65:195-202.

30. Marvan F, Vernerova E, Samek M, Reisnervov H, Nemec J, Martakova R. Aflatoxin B1 residues in the organs of young poultry. Biologicke Chem Vet (Praha). 1983;24:85-92.

31. Petr T, Barta I, Turek B. In vitro effect of mutagenic activity of aflatoxin B1. Hyg Epidemiol Microbiol Immunol (Prague). 1995;34:123-128.

32. Rastogi R, Srivastava AK, Rastogi AK. Long term effect of aflatoxin $B 1$ on lipid peroxidation in rat liver and kidney: Effect of picroliv and silymarin. Phytotherapy Res. 2001;15:307-310.

33. Umarani M, Shanthi $P$, Sachdanandam P. Protective effect of Kalpaamruthaain combating the oxidative stress posed by aflatoxin B1-induced hepatocellular carcinoma with special reference to flavonoid structure-activity relationship. Liver Int. 2008;28:200-213.

34. Choudhary A, Verma RJ. Ameliorative effects of black tea extract on aflatoxin induced lipid peroxidation in the liver of mice. Food Chem Toxicol. 2005;43:99-104.

35. Niki E, Yoshida Y, Saito Y, Noguchi N. Lipid peroxidation: Mechanisms, inhibition, and biological effects. Biochem Biophys Res Commun. 2005;338:668-676.

36. Naaz F, Abdin MZ, Javed S. Protective effect of esculin against prooxidant aflatoxin B1-induced nephrotoxicity in mice. Mycotoxin Res. 2014;30:25-32.

37. Sun LH, Lei MY, Zhang NY, Zhao L, Krumm CS, Qi DS. Hepatotoxic effects of mycotoxin combinations in mice. Food Chem Toxicol. 2014;74:289-293.

38. Wang F, Shu G, Peng X, et al. Protective effects of sodium selenite against aflatoxin B1-induced oxidative stress and apoptosis in broiler spleen. Int J Environ Res Public Health. 2013;10:2834-2844.

39. Janssen YM, Van Houten B, Borm PJ, Mossman BT. Cell and tissue responses to oxidative damage. Lab Invest. 1993;69:261-274.

40. Larsson P, Busk L, Tjalve H. Hepatic and extrahepatic bioactivation and GSH conjugation of aflatoxin B1 in sheep. Carcinogenesis. 1994;15:947-955.

41. Raney KD, Meyer DJ, Ketterer B, Harris TM, Guengerich FP. Glutathione conjugation of aflatoxin B1 exo- and endoepoxides by rat and human glutathione $S$ transferases. Chem Res Toxicol. 1992;5:470-478.

42. Nakae D, Konishi Y, Farber JL. A role for oxygen radicals in the hepatotoxicity of aflatoxin B1 and dimethyl nitrosamine. Proc Jap Cancer Assoc. 1987;38.

43. Verma RJ, Nair A. Ameliorative effect of vitamin E on aflatoxininduced lipid peroxidation in the testis of mice. Asian J Androl. 2001;3:217-221.

44. Banu GS, Kumar G, Murugesan AG. Ethanolic leaves extract of Trianthema portulacastrum $\mathrm{L}$. ameliorates aflatoxin $\mathrm{B} 1$ induced hepatic damage in rats. Indian J Clin Biochem. 2009;24:250-256.

45. Shen HM, Ong CH, Lee BL, Shi C. Aflatoxin B1-induced 8- hydroxydeoxyguanosine formation in rat hepatic DNA. Carcinogenesis. 1995;16:419-422.

46. Maslova GT, Boboriko TL. Effect of antioxidants on the status of the antioxidative system in cerebral ischemia and reperfusion injury. Ukr Biokhim Zh. 1990;62:101-105.

47. Odin AP. Vitamins as antimutagens: Advantages and some possible mechanisms of antimutagenic action. Mutat Res. 1997;386:39-67.

48. Thamilselvan S, Menon M. Vitamin E therapy prevents hyperoxaluria induced calcium oxalate crystal deposition in the kidney by improving renal tissue antioxidant status. BJU Int. 2005;96:117-126.

49. Kalengayi MM, Desmet VJ. Sequential histological and histochemi- cal study of the rat liver during aflatoxin B1 induced carcinogenesis. Cancer Res. 1975;35:2845-2852.

50. Plaa GL, Hewitt WR. Detection and evolution of chemically induced liver injury. In: Hayes, AW. (Ed.), Principles and Methods of Toxicology. Raven press, New York 1986;401-441.

51. Wang CJ, Shiow SJ, Lin JK. Effects of crocetin on the hepatotoxicity and hepatic DNA binding of aflatoxin B1 in rats. Carcinogenesis. 1991;12:459-462.

52. Yin SJ, Kao MC, Lee SC. Sequential biochemical and histological changes in rats treated with aflatoxin B1. Brit J Cancer. 1980;42:319-325.

53. Abdulmajeed NA. Therapeutic ability of some plant extracts on aflatoxin B1 induced renal and cardiac damage. Arab J Chem. 2011;4:1-10.

54. Mannaa FA, Abdel-Wahhab KG, Abdel-Wahhab MA. Prevention of cardiotoxicity of aflatoxin B1 via dietary supplementation of papaya fruit extracts in rats. Cytotechnology. 2014;66:327-334.

55. Pasha TN, Farooq MU, Khattak FM, Jabbar MA, Khan AD. Effectiveness of sodium bentonite and two commercial products as aflatoxin absorbents in diets for broiler chickens. Anim Feed Sci Technol. 2007;132:103-110.

56. Shi D, Liao S, Guo S, Li H, Yang M, Tang Z. Protective effects of selenium on aflatoxinB1-induced mitochondrial permeability transition, DNA damage, andhistological alterations in duckling liver. Biol Trace Elem Res. 2015;163:162-168.

57. Vayalil PK. Antioxidant and antimutagenic properties of aqueous extract of date fruit (Phoenix dactylifera L. Arecaceae). J Agric Food. Chem 2002;50:610-617.

58. Raju MVLN, Devegowda G. Influence of esterified-glucomannan on performance and organ morphology, serum biochemistry and haematology in broilers exposed to individual and combined mycotoxicosis (aflatoxin, ochratoxin and T-2 toxin). Br Poult Sci. 2000;41:640-650.

59. Yousef MI, Salem MH, Kamel KI, Hassan GA, El-Nouty FD. Influence of ascorbic acid supplementation on the haematological and clinical biochemistry parameters of male rabbits exposed to aflatoxin B1. J Environ Sci Health B. 2003;38:193-209.

60. Lorz C, Justo P, Sanz A, Subira D, Egido J, Ortiz A. Paracetomol induced renal tubular injury a role for ER stress. J Am Soc Nephrol. 2004;15:380-389.

61. Rati ER, Shantha T, Ramesh HP. Effect of long term feeding and withdrawal of aflatoxin B1 and ochratoxin A on kidney cell transformation in albino rats. Indian J Exp Biol. 1991;29:813-817.

62. Abdel-Wahhab MA, Nada SA, Amra HA. Effect of aluminosilicate and bentonite on aflatoxin-induced developmental toxicity in rats. J App/ Toxicol. 1999;19:199-204.

63. Verma RJ, Raval PJ. Alterations in erythrocytes during induced chronic aflatoxicosis in rabbits. Bull Environ Contam Toxicol. 1992;49:861-865. 